\title{
Penicillin binding protein 3 of Staphylococcus aureus NCTC 8325-4 binds and activates human plasminogen
}

Riikka Kylväjä ${ }^{1,2}$, Tuomas Ojalehto ${ }^{1,3}$, Veera Kainulainen ${ }^{1,4}$, Ritva Virkola ${ }^{1}$ and Benita Westerlund-Wikström ${ }^{1 *}$ (0)

\begin{abstract}
Background: Staphylococcus aureus is a versatile pathogen expressing a number of virulence-associated adhesive molecules. In a previous study, we generated in a secretion-competent Escherichia coli strain a library of random FLAG-tag positive (FTP) polypeptides of S. aureus. To identify adhesive proteins and gain additional knowledge on putative virulence factors of $S$. aureus, we here screened the FTP library against human serum proteins.
\end{abstract}

Findings: Staphylococcus aureus NCTC 8325-4, origin of the FTP library, adhered to immobilized plasminogen in vitro. In an enzyme-linked immunoassay a C-terminal part of penicillin binding protein 3 (PBP3), included in the FTP library, bound to immobilized plasminogen. We expressed and purified full-length PBP3 and its C-terminal fragments as recombinant proteins. In a time-resolved fluorometry — based assay the PBP3 polypeptides bound to immobilized plasminogen. The polypeptides enhanced formation of plasmin from plasminogen as analyzed by cleavage of a chromogenic plasmin substrate.

Conclusions: The present findings, although preliminary, demonstrate reliably that S. aureus NCTC 8325-4 adheres to immobilized plasminogen in vitro and that the adhesion may be mediated by a C-terminal fragment of the PBP3 protein. The full length PBP3 and the penicillin binding C-terminal domain of PBP3 expressed as recombinant proteins bound plasminogen and activated plasminogen to plasmin. These phenomena were inhibited by the lysine analogue $\varepsilon$-aminocaproic acid suggesting that the binding is mediated by lysine residues. A detailed molecular description of surface molecules enhancing the virulence of $S$. aureus will aid in understanding of its pathogenicity and help in design of antibacterial drugs in the future.

Keywords: Staphylococcus aureus, Penicillin binding protein, Plasminogen, Plasmin, Adhesion

\section{Findings}

\section{Research background}

The human plasminogen (Plg)/plasmin system is a key player in the tightly controlled blood fibrinolytic pathway that results in dissolving small, developing blood clots by rapid, non-specific, proteolytic events $[1,2]$. Plg circulates in blood as a proenzyme in two inactive forms: Glu-Plg and Lys-Plg, which are activated to the serine protease plasmin by two physiological Plg activators, tissue-type Plg activator (tPA) and urokinase Plg activator

\footnotetext{
*Correspondence: benita.westerlund@helsinki.fi

${ }^{1}$ General Microbiology, Department of Biosciences, University of Helsinki,

P.O.Box 56, FI-00014 University of Helsinki, Helsinki, Finland

Full list of author information is available at the end of the article
}

(uPA) [3-5]. The conversion of free Plg to plasmin by soluble activators in plasma is inefficient and fibrinolysis is generally initiated as the fibrin network in blood clots binds Plg that is then converted by tPA into active plasmin [2]. uPA binds to uPA receptors on target cells where it activates plasminogen and the event leads to degradation of extracellular matrix and regulation of cell migration, adhesion and proliferation [5, 6].

Many bacterial species can take advantage of the host's fibrinolytic system when they disseminate within the host and several bacterial species are known for their ability to generate a proteolytic surface from the human $\mathrm{Plg} /$ plasmin system. This enables bacteria to break out from blood clots and e.g. degrade components of the 
extracellular matrix, complement system or tissues of the host [7-10]. These bacterial species express bacterial $\mathrm{Plg}$ activators and Plg receptors by which soluble Plg is immobilized onto the bacterial cell surface. Examples of bacterial Plg activators and receptors are the Pla protein of Yersinia pestis, streptokinase of streptococci as well as glyceraldehyde 3-phosphate dehydrogenase and enolase of Lactobacillus and streptococci [11-17].

Staphylococcus aureus colonizes the human nasopharynx often without adverse effects $[18,19]$. However, this opportunistic pathogen is also the infectious agent in e.g. boils and furuncles and in more severe diseases such as bacteremia or endocarditis [20]. For preventive measures and treatment of $S$. aureus infections, it is important to identify the molecular mechanisms underlying colonization and state of infection in human beings. Similarly to some other pathogenic bacteria, S. aureus can generate a proteolytic surface that assists in invasive infections and has been shown to express the Plg activator staphylokinase as well as various receptors for Plg on its surface [13, $21,22]$. In this report, our aim was to analyze by an alternative approach, whether there are unknown proteins of S. aureus that bind and activate Plg and thereby increase its arsenal of virulence factors.

\section{Methods \\ Bacterial strains and growth conditions}

The Escherichia coli -based library secreting randomlength FLAG-tag positive (FTP) polypeptides of S. aureus as well as the nucleotide sequences of each $S$. aureus gene fragment in the library were available from previous work in our laboratory [23]. Briefly, the library consists of randomly fragmented chromosomal DNA of S. aureus subsp. aureus NCTC 8325-4 (from now on $S$. aureus NCTC 8325-4). The fragments are mainly $250-1000 \mathrm{bp}$ in length, distributed randomly and evenly on the $S$. aureus NCTC 8325-4 chromosome. The library was generated in our expression vector, which facilitates secretion of foreign FLAG-tagged polypeptides into the growth medium of $E$. coli MKS12 [23]. The library, which covers approximately $32 \%$ of the staphylococcal proteome, includes 1663 clones that cover 950 individual gene sequences expressing FTP polypeptides of $S$. aureus secreted into the $E$. coli MKS12 growth medium. Most of the sequences did not contain a known secretion signal. The folding state of the FTP polypeptides in the growth medium has not been analyzed. The clones of the E. coli MKS12 library were cultured in $300 \mu \mathrm{l}$ Luria-Bertani broth (LB) supplied with ampicillin $(150 \mu \mathrm{g} / \mathrm{ml})$ on 96 -well polystyrene plates statically overnight at $37^{\circ} \mathrm{C}$ or statically in $3 \mathrm{ml} \mathrm{N}$-minimal medium as described by Majander et al. [24]. Prior to protein analysis, the growth medium was clarified by centrifugation twice as described by Kylväjä et al. [23].
Enterococcus faecium ATCC 19434, Lactobacillus crispatus ST1 and S. aureus NCTC 8325-4 were available from previous work [23, 25] (Ritva Virkola personal communications). E. coli BL21 (AI) $\Delta s l y D$ (F-ompT gal dcm lon $h s d S B(\mathrm{rB}-\mathrm{mB}-)$ araB::T7RNAP-tetA $\Delta s l y D:: c a t)$ originally provided by Michael S. Donnenberg (University of Maryland) was available from previous work [26, 27]. E. coli BL21 (DE3) was from Novagen. E. faecium ATCC 19434 and S. aureus NCTC 8325-4 were grown shaking in $10 \mathrm{ml}$ Todd-Hewitt broth (Difco; BD Biosciences) for $18 \mathrm{~h}$ at $37^{\circ} \mathrm{C}$. L. crispatus ST1 was cultured statically in $10 \mathrm{ml}$ de Man, Rogosa and Sharpe broth (MRS; Difco) for $18 \mathrm{~h}$ at $37^{\circ} \mathrm{C}$. E. coli BL21 (AI) $\Delta s l y D$ (pREP4) and BL21 (DE3) were grown in LB broth or on LB agar plates overnight at $37{ }^{\circ} \mathrm{C}$ with appropriate antibiotics. The repressor plasmid pREP4 was used for repression of expression from the $\mathrm{pQE}$-type of vectors (Qiagen). To purify the HisPBP3 recombinant proteins, the hosts 1) E. coli BL21 (AI) (pREP4) $\Delta s l y D$ harboring the expression plasmid pQE30/ PBP3-F, and 2) BL21 (DE3) (pREP4) harboring pET45b/ PBP3-C and $\mathrm{pET} 45 \mathrm{~b} / \mathrm{PBP} 3-\mathrm{C}_{\mathrm{S} 634}$ were grown shaking overnight at $37{ }^{\circ} \mathrm{C}$ in LB broth with antibiotics $(\mathrm{Km}$ $25 \mu \mathrm{g} / \mathrm{ml}$ and Amp $150 \mu \mathrm{g} / \mathrm{ml}$ ) and diluted 1/20 in LB broth without ampicillin, to avoid binding of ampicillin to the expressed PBP3 derivatives. Then, (1) E. coli BL21 (AI) $\Delta$ slyD (pQE30/PBP3-F) was grown for $2 \mathrm{~h}$ at $37{ }^{\circ} \mathrm{C}$ and induced with $1 \mathrm{mM}$ IPTG for $2 \mathrm{~h}$ at $4{ }^{\circ} \mathrm{C}$, whereas (2) BL21 (DE3) (pET45b/PBP3-C) and BL21 (DE3) (pET45b/ PBP3- $\mathrm{C}_{\mathrm{S} 634}$ ) were grown for $6 \mathrm{~h}$ at $37^{\circ} \mathrm{C}$ before induction with $2 \mathrm{mM}$ IPTG for $1 \mathrm{~h}$ at $37^{\circ} \mathrm{C}$. The cells used in recombinant protein expression were washed once with PBS, pelleted and stored at $-20^{\circ} \mathrm{C}$.

\section{Adhesion of bacterial cells to immobilized Plg}

Human Glu-plasminogen (Glu-Plg; American Diagnostica) and bovine serum albumin (BSA; Sigma-Aldrich) were immobilized on Diagnostic StarFrost slides (Waldemar Knittel, Braunschweig) by applying $40 \mu \mathrm{l} \mathrm{Glu-Plg}$ $(20 \mu \mathrm{g} / \mathrm{ml})$ and $40 \mu \mathrm{l} \mathrm{BSA}(25 \mu \mathrm{g} / \mathrm{ml})$ in phosphate-buffered saline, $\mathrm{pH} 7.1$ (PBS) onto the slides. The slides were incubated in a moist chamber for $18 \mathrm{~h}$ at $20{ }^{\circ} \mathrm{C}$, washed slowly shaking for $3 \mathrm{~min}$ in $0.1 \% \mathrm{BSA} / \mathrm{PBS}$ and blocked statically in $2 \% \mathrm{BSA} / \mathrm{PBS}$ for $2 \mathrm{~h}$ at $20^{\circ} \mathrm{C}$. After washing the slides slowly shaking $3 \times 5 \mathrm{~min}$ in $0.1 \% \mathrm{BSA} /$ PBS, $40 \mu \mathrm{l}$ of bacterial suspensions $\left(5 \times 10^{8}\right.$ bacteria $/ \mathrm{ml}$ of PBS) were applied onto the slides, which were then incubated statically in a moist chamber for $2 \mathrm{~h}$ at $20^{\circ} \mathrm{C}$. The slides were washed slowly shaking $3 \times 3 \mathrm{~min}$ in $0.1 \% \mathrm{BSA} / \mathrm{PBS}$ and left to dry for $18 \mathrm{~h}$ at $20{ }^{\circ} \mathrm{C}$. Adhered bacteria were visualized by staining of the slides with $0.2 \%$ Loeffler methylene blue (Merck) for $3 \mathrm{~min}$. The slides were washed in tap water, left to dry at $20^{\circ} \mathrm{C}$ and the number of adhered bacteria in 20 randomly chosen 
microscopic fields (of $3.4 \times 10^{4} \mu \mathrm{m}^{2}$ ) was quantified for each bacterial strain and each target protein using ImagePro Plus, version 4.0 TM (Media Cybernetics, Inc., USA) and Image 1.47 software (National Institutes of Health, USA) for analysis of bacterial adhesion. The experiment was repeated three times and the result of one representative experiment was used for calculation of average number of adhered bacteria and the standard deviation in 20 randomly chosen microscopic fields.

\section{Primary screening of the binding of FTP polypeptides to immobilized Plg}

Cleared supernatants of the FTP clones were prepared as described by Kylväää et al. [23] and $100 \mu$ l of each cleared supernatant was analyzed for binding to immobilized Glu-Plg (100 nM) in an enzyme-linked immunoassay (ELISA). Bound FTP peptides were detected with anti-FLAG ${ }^{\circledR}$ M2 monoclonal antibody $(0.5 \mu \mathrm{g} / \mathrm{ml}$ in $1 \%$ BSA/PBS; Sigma-Aldrich, RRID:AB_439685) and alkaline phosphatase-conjugated anti-mouse antibody $(1 \mu \mathrm{g} /$ $\mathrm{ml}$ in $1 \% \mathrm{BSA} / \mathrm{PBS}$ ), and the absorbance was measured in a Multiscan Titertek recorder (Eflab) at $405 \mathrm{~nm}$ as described for other target proteins in Kylväjä et al. [23]. Clarified, cell-free supernatant of MKS12 (pSRP18/0), carrying an empty vector and the clone named $\triangle \mathrm{ArcB}$, encoding a $\mathrm{C}$-terminal fragment of the $\mathrm{ArcB}$ subunit of a multidrug efflux pump (locus tag SAOUHSC 02525), as well as His-tagged enolase of L. crispatus ST1 (ST1 Eno) were available from previous work $[12,23]$ and were used as controls.

\section{Construction and purification of His-tagged PBP3 proteins}

We constructed the following $\mathrm{N}$-terminally His-tagged PBP3 recombinant proteins: (a) $\mathrm{PBP} 3-\mathrm{C}_{\mathrm{S} 634}$, which started at the beginning of the transpeptidase domain at residue E327 and was truncated at the $\mathrm{C}$-terminus identically to that of the FTP library polypeptide, (b) a fulllength PBP3 polypeptide named PBP3-F, which started from residue D58 and thereby lacked the membrane anchor domain, and (c) the PBP3 C-terminal domain named PBP3-C, which started from residue E327 and covered the penicillin binding transpeptidase domain [28, 29]. To construct the described recombinant proteins, the $p b p \mathrm{C}$ gene fragment encoding PBP3-F was cloned into the SphI/Pst restriction site of pQE30 (Qiagen) and the gene fragments encoding PBP3-C and PBP3- $\mathrm{C}_{\mathrm{S} 634}$ carrying two additional $\mathrm{N}$-terminal His-residues, to enhance the binding to the affinity matrix used for protein purification, were cloned into the $P m l \mathrm{I} / B l p \mathrm{I}$ restriction site in pET45b (Novagen). Primers used were designed on the basis of the $p b p C$ sequence of $S$. aureus NCTC 8325 (locus SAOUHSC_01652) as follows: forward of PBP3-F: 5'CCCGCATGCGATGAAAACATTACAGTGAATGAG
TCTG; reverse of PBP3-F: 5'GGGCTGCAGTTATTTG TCTTTGTCTTTATTTTTATCATC; forward of PBP3-C and PBP3-C $\mathrm{C}_{\mathrm{S} 634}: 5^{\prime} \mathrm{CACCACGAAGTAGAAGCATTATT}$ AGATAAACAAATTAAG; reverse of PBP3-C: 5'GGGC TCAGCTTATTTGTCTTTGTCTTTATTTTTATCATC; reverse of PBP3- $\mathrm{C}_{\mathrm{S} 634}: 5^{\prime}$ GGGGCTCAGCTTAAGAGTTAACTCTTGGCTCTC. Plasmid pQE30/PBP3-F was transformed into E. coli BL21 (AI) (pREP4) $\Delta s l y D$ to decrease the contamination of the endogenous SlyD protein of $E$. coli in the affinity purification, and plasmids pET45b/PBP3-C and pET45b/PBP3-C $\mathrm{S} 634_{4}$ into E. coli BL21 (DE3) for expression of proteins.

Cells expressing the N-terminally His-tagged PBP3F were lysed with BugBuster ${ }^{\circledR}$ Master Mix $(10 \mathrm{ml}$ BugBuster/cells pelleted from $100 \mathrm{ml}$ culture) (Novagen). Protein present in the soluble cell fraction was purified using nickel-nitrilotriacetic acid (Ni-NTA) metal-affinity chromatography matrix under native conditions according to QIAexpress System (Qiagen) with the following minor modifications. All buffers were supplemented with $10 \%$ glycerol to stabilize the recombinant proteins. In addition, the lysis buffer was supplemented with $15 \mathrm{mM}$ imidazole and the wash buffer with $40 \mathrm{mM}$ imidazole. Cells expressing the $\mathrm{N}$-terminally His-tagged PBP3-C and PBP3- $\mathrm{C}_{\mathrm{S} 634}$ were lysed with QIAexpress native lysis buffer ( $5 \mathrm{ml} / \mathrm{g}$ cells), where after PBP3- $\mathrm{C}_{\mathrm{S} 634}$ and PBP3-C in the non-soluble fractions were solubilized with QIAexpress Urea lysis buffer $(10 \mathrm{ml} / \mathrm{g}$ pellet). The proteins were purified under denaturing conditions using Ni-NTA agarose according to manufacturer's instructions. After purification under denaturing conditions, the PBP3-C and $\mathrm{PBP3}-\mathrm{C}_{\mathrm{S} 634}$ proteins were refolded by changing the urea-containing elution buffer to PBS containing $10 \%$ glycerol in a PD-10 gel filtration column (GE Healthcare). The purification process was monitored by SDS-PAGE analysis and the concentration of the purified proteins was determined by analyzing the whole band intensity from Coomassie-stained SDS-PAGE gels, with BSA as a standard of known concentrations and using the TINA $2.09 \mathrm{c}$ software (Rayest Isotopen Meßgeräte). The secondary structure of the proteins was not assessed.

\section{Binding of purified His-tagged PBPs to soluble Plg}

The binding of purified His-tagged PBP3 proteins to soluble Plg was analyzed by time-resolved fluorometry developed by Hurmalainen et al. [12] and Kukkonen et al. [30] with minor modifications. Briefly, the concentration of all proteins to be analyzed for binding to Plg was adjusted to $625 \mathrm{nM}$ in PBS/10 \% glycerol and the analysis was assessed at a final concentration of $100 \mathrm{nM}$ in PBS (100 $\mu \mathrm{l} /$ well). The His-tagged PBP3 proteins, the positive control protein laminin (Lam; Sigma-Aldrich) [31] and negative control protein $\triangle \mathrm{NarG}$ (locus tag SAOUHSC 
02681) available from previous work [23], were immobilized on polystyrene microtiter plates overnight at $21{ }^{\circ} \mathrm{C}$, the plates were washed and blocked with $2 \% \mathrm{BSA} /$ PBS. Glu-Plg $(1 \mu \mathrm{g} /$ well $)$ was added to the wells and the plate was incubated for $4 \mathrm{~h}$ at $21{ }^{\circ} \mathrm{C}$. For inhibition studies, Glu-Plg in PBS/0.1 \% Tween 20 was incubated with $\varepsilon$-aminocaproic acid (EACA; $10 \mathrm{mM}$ ) for $15 \mathrm{~min}$ at $21^{\circ} \mathrm{C}$ prior to its application onto the immobilized target proteins. The binding of Plg was assessed with parallel samples using polyclonal anti-human Plg IgG (720 ng/well, 2 h, $21{ }^{\circ} \mathrm{C}$; American Diagnostica, RRID: AB_400685) and $\mathrm{Eu}^{3+}$-labelled anti-rabbit IgG ( $80 \mathrm{ng} /$ well, $18 \mathrm{~h}, 4{ }^{\circ} \mathrm{C}$; PerkinElmer) and measured in a VICTOR ${ }^{\circledR}$ time-resolved fluorometer with DELFIA ${ }^{\circledR}$ enhancement solution (PerkinElmer) using filter settings $340 \mathrm{~nm}$ (excitation) and $615 \mathrm{~nm}$ (emission). The volume was $100 \mu \mathrm{l}$ in each step except for the enhancement solution that was used at $250 \mu \mathrm{l}$. The experiment was repeated twice with very similar outcomes. The average and standard deviation of two parallel samples were calculated on the basis of the results of one of the experiments.

\section{Formation of active plasmin by purified proteins}

His-tagged PBP3-F, PBP3-C and PBP3- $\mathrm{C}_{\mathrm{S} 634}(100 \mathrm{nM})$, Lam $(100 \mathrm{nM})$ and $\triangle \mathrm{NarG}(100 \mathrm{nM})$ in PBS/10 \% glycerol were mixed in polystyrene microtiter wells with Glu-Plg $(4 \mu \mathrm{g} /$ well), and the tissue-type Plg activator tPA (2 ng/well; Calbiochem) in PBS. Controls included were (1) wells without Plg, (2) wells without tPA, (3) wells without Plg and tPA, and (4) wells without His-tagged PBP3 proteins. The lacking reaction components were substituted with buffer. For inhibition studies, EACA $(0.73 \mathrm{mM})$ was added to the wells $5 \mathrm{~min}$ prior to Glu-Plg addition. The chromogenic plasmin substrate SS-2251 (H-D-Val-Leu-Lys-p-nitroanilinehydrochloride; Kabivitrum) was added $(0.45 \mathrm{mM})$ to all wells prior to measurement of the absorbance in a Multiscan Titertek recorder (Eflab) at $405 \mathrm{~nm}$ (time point $\mathrm{T}_{0}$ ). Final volume in each well was $200 \mu \mathrm{l}$. The absorbance was measured at intervals of $15-30 \mathrm{~min}$ for $4.5 \mathrm{~h}$ and values of $\mathrm{T}_{0}$ were subtracted from measurements of the other time points as well as the background level of the activation of substrate SS-2251 in buffer. The experiment with parallel samples was repeated twice; the average and standard deviation of two parallel samples were calculated on the basis of the results of one of the experiments.

\section{Results and discussion}

We have previously generated a library of random FLAGtag positive polypeptides (FTP library) of strain S. aureus NCTC 8325-4 in the secretion-competent E. coliK12 derivative called MKS12. This strain can secrete heterologous proteins into the growth medium [23, 24] and the heterologous polypeptides can be analyzed directly in the growth medium of $E$. coli MKS12 for binding to various target molecules as described by Majander et al. [24] and Kylväjä et al. [23]. In this report, we first analyzed the adhesion of $S$. aureus NCTC 8325-4 cells to Plg and then assessed the binding to Plg in vitro by $S$. aureus NCTC 8325-4 polypeptides present in the E. coli MKS12-based FTP library.

Adhesion of E. faecium ATCC 19434, L. crispatus ST1 and S. aureus NCTC 8325-4 to immobilized Plg and BSA was assessed. We chose the strain $S$. aureus NCTC 8325-4 for the adhesion assay, since its chromosome had been used when we constructed the FTP library [23], which also was used for screening purposes in this report. To our knowledge, binding of Plg has been demonstrated with other $S$. aureus strains [21, 22, 32], but never with the commonly used laboratory strain $S$. aureus NCTC 8325-4. L. crispatus ST1 has previously been proven to bind and activate Plg and it was used here as a positive control [12, 13]. E. faecium has not been demonstrated to interact with Plg and was therefore applied as a putative negative control strain here. In the in vitro adhesion assay, S. aureus adhered efficiently to Plg (ca 4830 bacteria per microscopic field), but not to BSA (Fig. 1). The adhesive capacity of $L$. crispatus to Plg was much lower (ca 2580 bacteria per microscopic field), whereas E. faecium did not significantly adhere to Plg or BSA (primary data is shown in Additional file 1).

Staphylococcus aureus is known to express the single plasminogen activator staphylokinase and a few plasminogen receptors, such as $\mathrm{Sbi}$, Ebh and $\alpha$-enolase, on its surface [13, 22, 32, 33]. We next wanted to examine

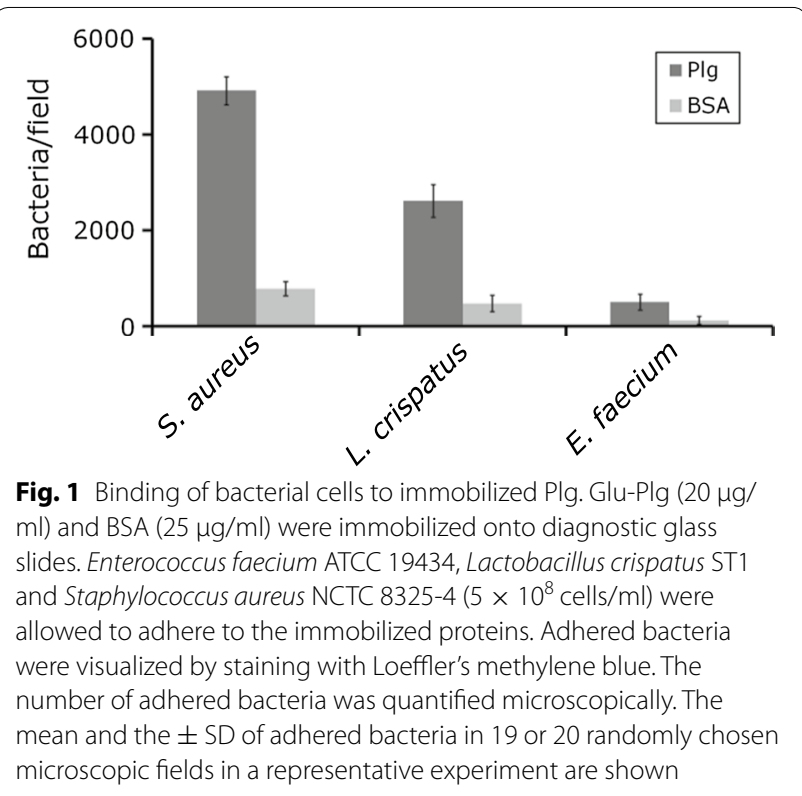


whether S. aureus NCTC 8325-4 expresses putative Plg receptors in addition to the well-known ones. To explore that, we screened the polypeptides of the FTP library for their binding to Plg (Fig. 2a, primary data is shown in Additional file 2). One specific library clone, named $\triangle \mathrm{PBP} 3$, attracted our attention. The extracellular polypeptide secreted by the $\triangle \mathrm{PBP} 3$ clone bound to Plg in an ELISA assay much more efficiently than peptides secreted by any other clone of the FTP library (Fig. 2a). We next confirmed the result obtained from the screening experiment with the Plg-binding clone $\triangle \mathrm{PBP} 3$ (Fig. 2b). The clarified growth medium from the $\triangle \mathrm{PBP} 3$ library clone bound to immobilized plasminogen as well as the enolase of L. crispatus ST1 (ST1 Eno), reported to bind plasminogen $[12,13]$. The clarified growth medium of the clone named $\triangle \mathrm{ArcB}$ or the host strain MKS12 (pSRP18/0) used as negative controls did not bind to immobilized Plg (Fig. 2b, primary data is shown in Additional file 2). Based on the sequence of the S. aureus gene carried by clone $\triangle \mathrm{PBP} 3$, the gene product and thereby the polypeptide secreted into the $E$. coli growth medium is a C-terminal fragment of penicillin binding protein 3 (PBP3; locus tag SAOUHSC 02430) (Fig. 3) [23].

Penicillin binding proteins (PBPs) are involved in the last steps of peptidoglycan biosynthesis in bacteria [34]. The penicillin binding domains of PBPs are targets of $\beta$-lactam antibiotics including penicillin, hence the name $[28,35]$. The $\beta$-lactam antibiotics mimic the PBP substrate and bind irreversibly to a conserved serine residue in the active groove of the enzyme, thereby inhibiting its activity $[36,37]$. PBPs are multimodular proteins that are classified into high-molecular-weight (HMW) and lowmolecular-weight (LMW) PBPs. HMW PBPs are further classified as class A or class B PBPs and the LMW
PBPs that function as carboxypeptidases are also referred to as class C PBSs [35]. The HMW PBPs of class A are bifunctional enzymes containing (1) a non-penicillin binding glycosyltransferase (GTase) domain that catalyzes elongation of the glycan chain of peptidoglycan and (2) a C-terminal, penicillin binding transpeptidase (TPase) domain that crosslinks the peptidoglycan. The only known enzymatic function for class B HMW PBPs is the TPase activity of the C-terminal penicillin binding domain (Fig. 3). The $\mathrm{N}$-terminal dimerization domain of class B PBPs has been postulated to act as an intramolecular chaperone that assists the proper folding of the C-terminal domain or have a role in cell morphogenesis $[28,38]$.

PBP3 is one of the four penicillin binding proteins (named PBP1-PBP4) of methicillin sensitive S. aureus and belongs to class B HMW PBPs [39-42]. PBP3 is considered as an enzyme non-essential for growth and survival of S. aureus [42]. The specific role for PBP3 is not known. The cell morphology of mutant strains lacking the $p b p C$ gene that encodes PBP3 do not differ significantly from cells expressing PBP3, but the mutant cells exhibit increased methicillin resistance [29, 42].

To verify the Plg binding properties of PBP3 that we observed with the $\triangle \mathrm{PBP} 3$ FTP polypeptide, we cloned and expressed an $\mathrm{N}$-terminally His-tagged polypeptide named PBP3- $\mathrm{C}_{\mathrm{S} 634}$, which started at the beginning of the transpeptidase domain at residue E327, and was truncated at the C-terminus identically to the FTP library polypeptide (Fig. 3). SDS-PAGE analysis of the purified PBP3- $C_{\mathrm{S} 634}$ polypeptide is shown in Fig. 4a. The binding of PBP3- $\mathrm{C}_{\mathrm{S} 634}$ to human Glu-Plg was assessed by timeresolved fluorometry, where the His-tagged PBP3- $\mathrm{C}_{\mathrm{S} 634}$ protein was immobilized in polystyrene wells and soluble
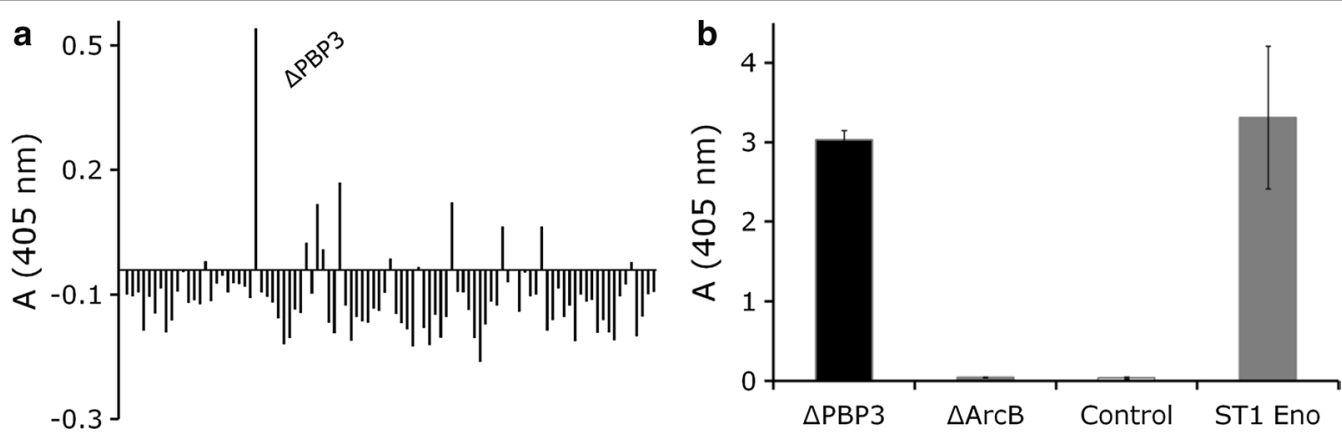

Fig. 2 Binding of cell-free growth medium of the FTP library clones to immobilized plasminogen. a Binding of clarified growth medium from 95 representative FTP library clones to immobilized plasminogen is shown. The clone encoding a fragment of S. aureus PBP3 is named $\triangle$ PBP3. Clarified growth medium of the 96th clone, the host strain MKS12 carrying the empty vector pSRP18/0, was used as the background level and the value obtained with this control was subtracted from the other results. The results were measured in ELISA plate reader at $\mathrm{A}_{405 \mathrm{~nm}}$. $\mathbf{b}$ Binding of the clarified growth medium from the $\triangle \mathrm{PBP} 3$ library clone to immobilized plasminogen is shown. Purified, His-tagged enolase of Lactobacillus crispatus ST1 (ST1 Eno) represents a positive control protein and the clarified supernatant from the clone named $\triangle A r C B$, encoding a fragment of S. aureus ArcB protein, represents the negative control. The binding of clarified supernatant from MKS12 (pSRP18/0), named as Control, is also shown. The results were measured in ELISA plate recorder at $A_{405 \mathrm{~nm}}$. The mean and \pm SD of duplicate samples from a representative experiment are shown 


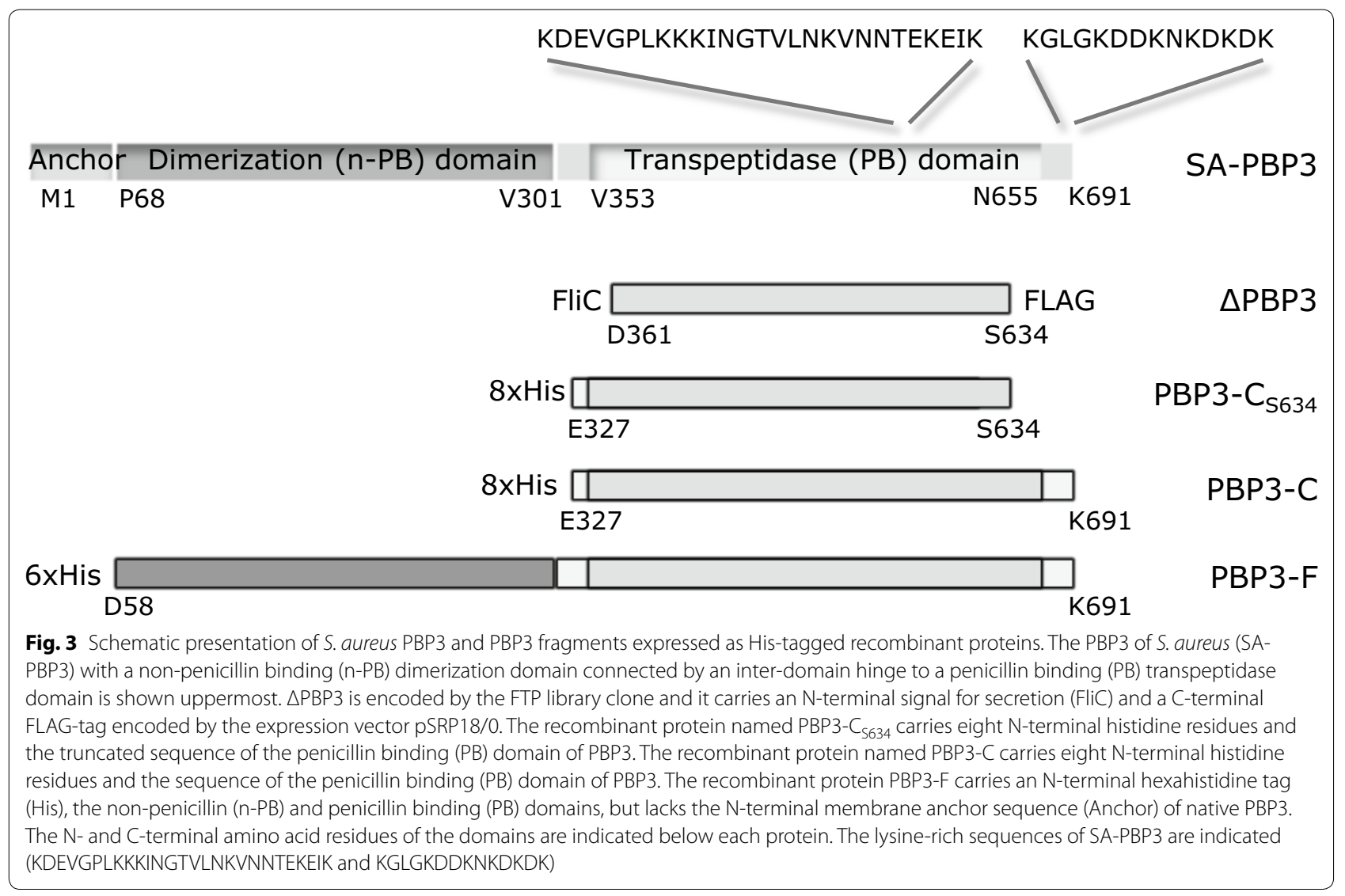

Plg was allowed to bind. This setup mimics the situation in vivo, where Plg receptors are attached to the bacterial surface and soluble Plg is recruited to the surface by the $\mathrm{Plg}$ receptors. Immobilization of $\mathrm{Plg} /$ plasmin onto the bacterial surface, or onto host tissues, enhances the plasmin formation and protects the activated plasmin from physiological inhibitors such as $\alpha 2$-antiplasmin $[1$, 4]. PBP3- $\mathrm{C}_{\mathrm{S} 634}$, as well as the control protein laminin, bound efficiently Plg, whereas $\Delta \mathrm{NarG}$, which was used as a negative control protein, did not bind Plg (Fig. 4a, Primary data is shown in Additional file 3). C-terminally located and internal repetitive lysine residues, as well as other positively charged amino acid motifs, present in various Plg-binding proteins are known to bind to the kringle domains of Plg. The lysine-mediated binding can be inhibited by the lysine analogue EACA [43-48]. The binding of immobilized PBP3- $\mathrm{C}_{\mathrm{S} 634}$ to soluble Plg was inhibited by EACA, which indicates that lysine residues are involved in the binding (Fig. 4a). PBP3 contains lysine residues at the ultimate $\mathrm{C}$-terminus (Fig. 3, SA-PBP3), but the $\triangle$ PBP3 FTP polypeptide and the PBP3- $\mathrm{C}_{\mathrm{S} 634}$ did not include the $\mathrm{C}$-terminal lysine-rich sequence of $\mathrm{PBP} 3$ (Fig. 3, $\triangle$ PBP3 and PBP3- $\mathrm{C}_{\mathrm{S} 634}$ ). The results obtained with truncated, recombinant $\mathrm{PBP} 3-\mathrm{C}$ polypeptides suggest that other residues than $\mathrm{C}$-terminal lysine residues are important in the binding of soluble Plg to PBP3 of $S$. aureus. This hypothesis is supported by the fact that $\triangle \mathrm{PBP} 3$ and PBP3- $\mathrm{C}_{\mathrm{S} 634}$ contain an internal lysinerich region (KDEVGPLKKKINGTVLNKVNNTEKEIK) located 104 amino acid residues $\mathrm{N}$-terminally from the ultimate C-terminus of PBP3 (Fig. 3). Enolase of streptococci has similarly been shown to bind and activate Plg via internal, surface-exposed lysine residues [49].

We next wanted to test the binding of the full length PBP3 and the full C-terminal transpeptidase domain of the PBP3 protein to soluble Plg similarly as we did with the PBP3- $\mathrm{C}_{\mathrm{S} 634}$ protein. The genes encoding the Histagged PBP3 polypeptide named PBP3-F, which started from residue D58 and thereby lacked the membrane anchor domain, and the His-tagged C-terminal domain named PBP3-C, which started from residue E327 and covered the penicillin binding transpeptidase domain of the protein [28, 29] (Fig. 3), were cloned and the corresponding gene products were purified. SDS-PAGE analysis of purified PBP3-F and PBP3-C is shown in Fig. 4b. PBP3-F and PBP3-C both bound soluble Plg similarly as the PBP3- $\mathrm{C}_{\mathrm{S} 634}$ protein and EACA inhibited the binding (Fig. 4b, Primary data is shown in Additional file 3). 

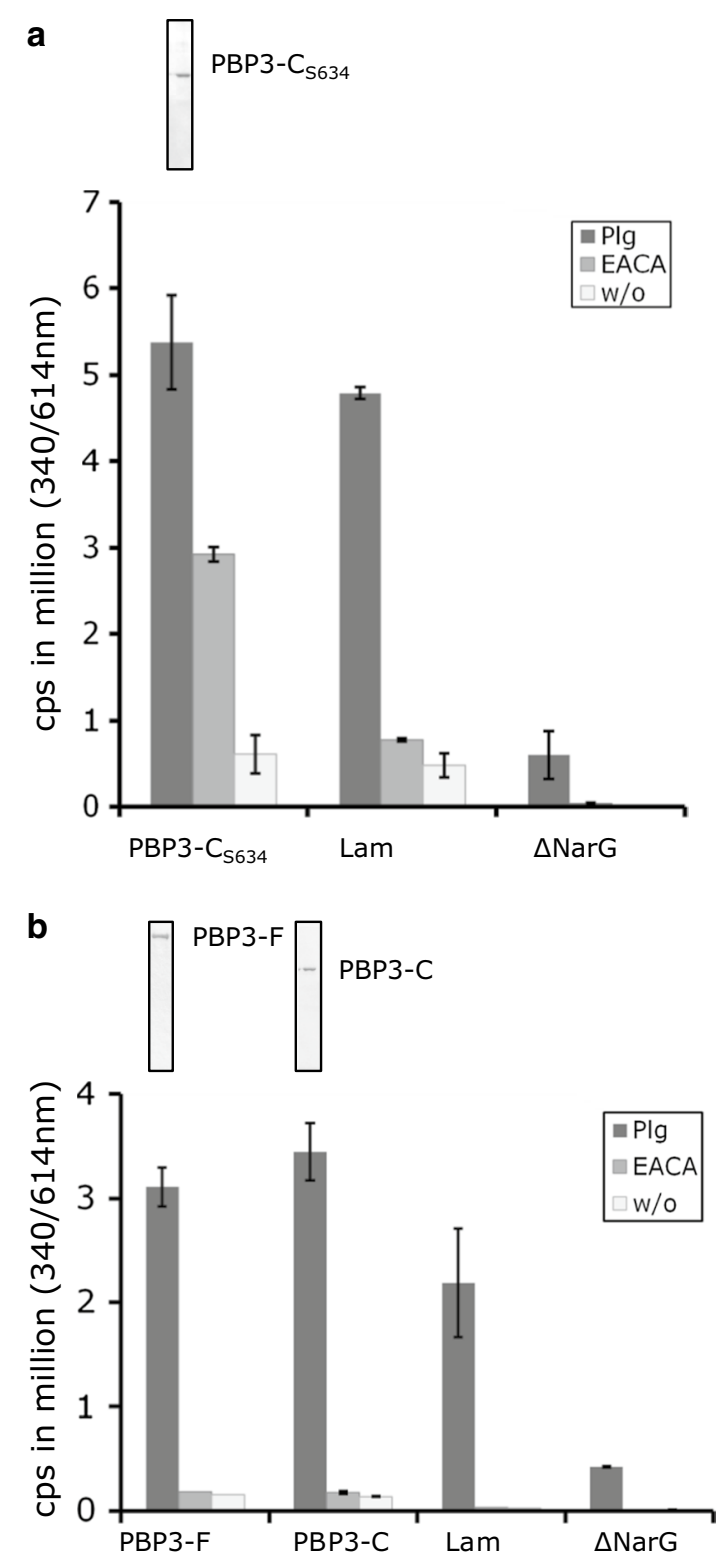

Fig. 4 Binding of soluble plasminogen to His-tagged recombinant PBP3 proteins. The binding of soluble plasminogen to immobilized a PBP3- $\mathrm{C}_{5634}$ and $\mathbf{b}$ PBP3-F and PBP3-C was measured with VICTOR ${ }^{\circledR}$ time-resolved fluorometer as counts per second (cps) at 340/615 nm. Laminin (Lam) and $\triangle N a r G$ were included as controls. The test included binding in the presence of the proteins to be tested and (i) Plg (black bars, Plg), (ii) Plg and EACA (grey bars, EACA), (iii) binding in the absence of Plg or EACA (white bars, w/O). The mean and the \pm SD of duplicate samples of one representative experiment are shown. SDS-PAGE analysis of the purified PBP3- $\mathrm{C}_{5634}$, PBP3-F and PBP3-C recombinant proteins are shown above the respective fluorometry results in figure $\mathbf{a}$ and $\mathbf{b}$

When soluble Plg is immobilized by Plg receptors on the bacterial surface in vivo, it is converted to active plasmin by the physiological activators tPA or uPA [10] or by bacterial activators [32]. We next assessed whether tPA activated the PBP3-bound, proteolytically inactive Plg into active plasmin. Our results, obtained by measuring the cleavage of a chromogenic plasmin substrate, showed that plasminogen was activated into plasmin in the presence of PBP3-F, PBP3-C or PBP3- $\mathrm{C}_{\mathrm{S} 634}$ and tPA (Fig. 5). The positive control protein laminin also enhanced tPAmediated activation of Plg into plasmin whereas $\triangle \mathrm{NarG}$ had no effect on plasmin formation. PBP3-F, PBP3-C, $\mathrm{PBP} 3-\mathrm{C}_{\mathrm{S} 634}$ or laminin did not activate $\mathrm{Plg}$ directly into plasmin when tPA was not present (Fig. 5, w/o tPA), indicating that PBP3 does not function as a direct Plg activator. The tPA mediated plasmin activity was not enhanced in the presence of EACA implying that lysine residues are important in the interaction of Plg and PBP3 proteins (Fig. 5, EACA). The binding of Plg to the putative Plg receptors $\mathrm{PBP3}-\mathrm{F}, \mathrm{PBP3}-\mathrm{C}$ or $\mathrm{PBP3}-\mathrm{C}_{\mathrm{S} 634}$ as well as the control protein laminin, was required for tPA mediated activity since Plg and tPA alone did not provoke plasmin activity (Fig. 5, Ctrls). Furthermore, our results show that PBP3-F, PBP3-C and PBP3- $\mathrm{C}_{\mathrm{S} 634}$ did not alone, when tPA and Plg were not present, cleave the chromogenic substrate although the PBP3 proteins contain an activesite serine similarly as the serine proteases that cleave the chromogenic substrates (Fig. 5, w/o tPA or Plg) [29, 50]. Primary data of Fig. 5 is shown in Additional file 4. Altogether these results imply that the PBP3 protein acts as a Plg receptor in vitro. The enhanced plasmin activity is mediated by tPA only after the inactive, soluble Plg is bound by PBP3-F, PBP3-C or PBP3- $\mathrm{C}_{\mathrm{S} 634}$ via internal lysine residues.

The penicillin binding domain of PBP3 that synthesizes the last steps in $S$. aureus cell wall polymerization is located outermost from the cell membrane in PBP3, but it is currently not known whether it is exposed e.g. during the cell wall turnover or released to the extracellular milieu. Surface exposure would enable binding of soluble Plg by this putative Plg receptor. The biological role of PBP3 and other PBPs in plasmin formation in vivo remains still to be revealed. Muthukrishnan et al. [51] have shown that planktonic, nasal carrier strains of $S$. aureus secrete PBPs among other molecules. Additionally, PBP2 of $S$. aureus has been shown to protrude to the extracellular environment in methicillin resistant S. aureus [52] and to be localized to membrane vesicles of S. aureus ATCC 14458 [53]. Other types of PBPs have been found in the exoproteome of other bacterial species, such as Clostridium difficile, Streptococcus agalactiae and Corynebacterium pseudotuberculosis [54-56]. These findings imply that PBPs might have moonlighting functions [57] outside the bacterial cell wall. In this study, the full length His-tagged PBP3 clearly bound Plg in vitro and enhanced the tPA mediated activation of bound plasminogen. The binding was localized to the C-terminal domain of PBP3, where repetitive internal 

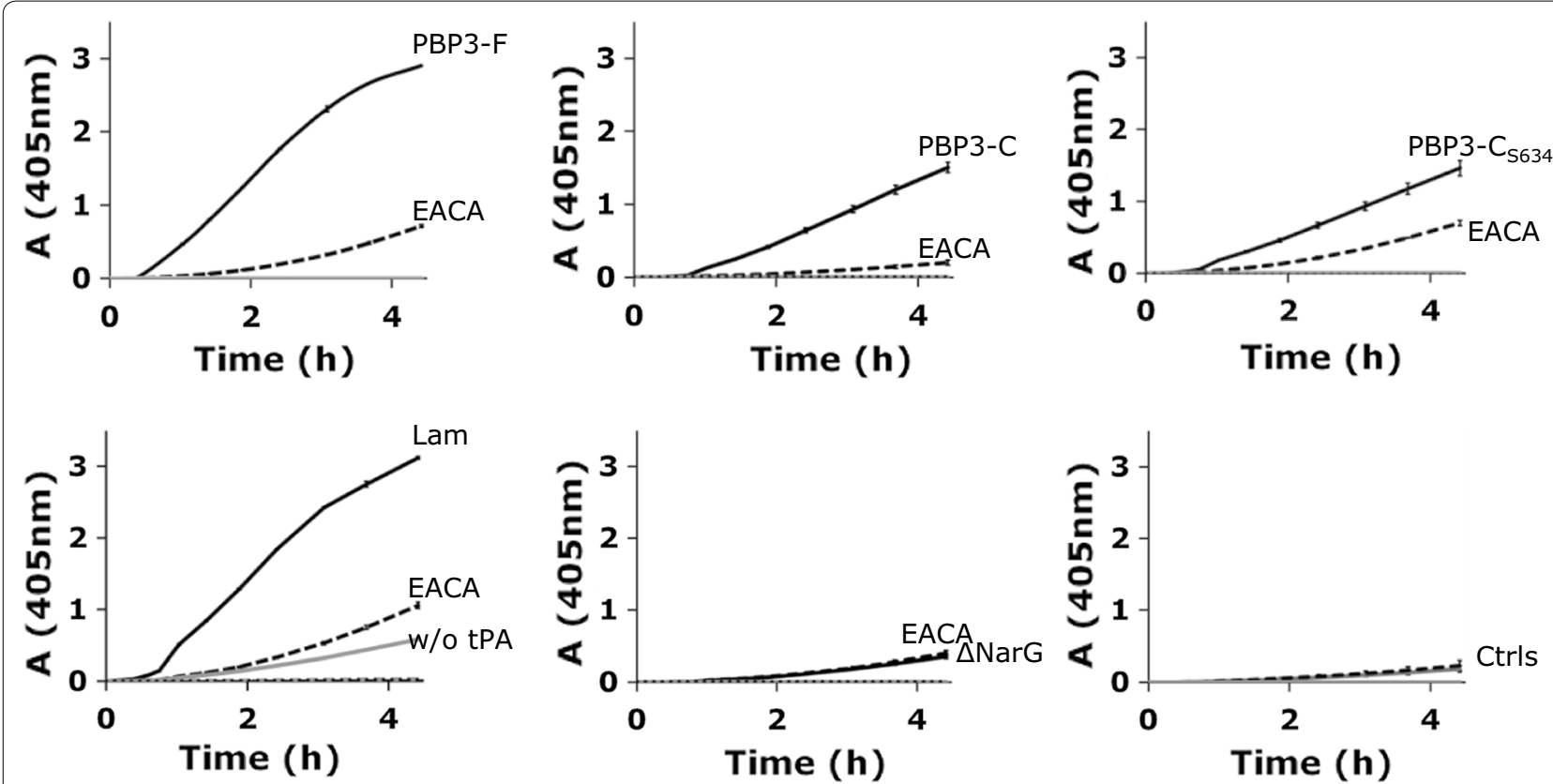

Fig. 5 Enhancement of plasmin formation by His-tagged recombinant PBP3 proteins. The activation of plasminogen to plasmin by PBP3-F, PBP3-C, PBP3- $C_{5634}$, Lam and $\triangle N$ arG was measured in ELISA plate recorder $\left(A_{405 \mathrm{~nm}}\right)$ at 15-30 min time intervals for $4.5 \mathrm{~h}$. The background level with buffer only (Bfr) is also shown. The test included plasminogen activation by the corresponding protein (PBP3-F, PBP3-C, PBP3- $\mathrm{C}_{5634}, \mathrm{Lam}, \triangle \mathrm{NarG}$ ) or buffer only (Ctrls) in the presence of (i) Plg, tPA and the substrate, (ii) Plg, tPA, EACA and the substrate (EACA), (iii) Plg and the substrate without tPA (w/o $t P A)$, iv) tPA and the substrate without Plg and (v) substrate in buffer. The mean and \pm SD of the duplicate samples from one representative experiment are shown

lysine residues reside. These results imply the putative role of PBP3 as a Plg receptor on the cell surface of S. aureus. However, the presence and the role of PBP3, and other PBPs, on cell surface or in the exoproteome of $S$. aureus should be further studied.

$\mathrm{Plg}$ activation is a well-known virulence trait of many bacterial species [11] and the activation might lead to invasive infections. S. aureus is carried in the nasopharynx by $20-40 \%$ of human population and the carrier status can lead to severe invasive infections $[58,59]$. The nasal carrier strains of $S$. aureus have been shown to secrete PBPs $[51,60]$ and their role in invasive infections should be further studied. The results presented in this study indicate that PBPs might have a moonlighting role as Plg receptors in invasive infections.

\section{Additional files}

Additional file 1. Primary data of bacterial adhesion to Plg and BSA (Fig. 1).

Additional file 2. Primary data of plasminogen binding by FTP library clones (Fig. 2).

Additional file 3. Primary data of Plg binding by recombinant proteins (Fig. 4).

Additional file 4. Primary data of Plg activation by recombinant proteins (Fig. 5).

\section{Abbreviations}

BSA: bovine serum albumin; PBP3-C: C-terminal domain of penicillin binding protein 3; EACA: $\varepsilon$-aminocaproic acid; ELISA: enzyme-linked immunoassay; FTP: FLAG-tag positive; PBP3-F: full length penicillin binding protein 3 without the membrane anchor domain; GTase: glycosyltransferase; HMW: high-molecular-weight; IPTG: isopropyl $\beta$-D-1-thiogalactopyranoside; LMW: low-molecular-weight; LB broth: Luria-Bertani broth; MRS broth: de Man, Rogosa and Sharpe broth; n-PB: non-penicillin binding; Ni-NTA: nickel-nitrilotriacetic acid; PB: penicillin binding; PBP: penicillin binding protein; PBS: phosphate-buffered saline; Plg: plasminogen; ST1 Eno: His-tagged enolase of L. crispatus ST1; tPA: tissue-type Plg activator; TPase: transpeptidase; UPA: urokinase Plg activator.

\section{Authors' contributions}

RK participated in the design of the study and interpretation of data, carried out the protein purifications and functional analysis with purified proteins in time-resolved fluorometry and ELISA (Figs. 2, 3, 4, 5), and drafted the manuscript. TO carried out the adherence assays with bacterial cells (Fig. 1). VK participated in development of the bacterial adhesion assay, the time-resolved fluorometry and purified the control protein ST1 Eno of L. crispatus ST1. She also participated in writing of the manuscript. RV participated in planning and supervision of the bacterial adhesion assay, and participated in writing of the manuscript. BWW directed the study, had the main responsibility for data interpretation and manuscript writing. All authors read and approved the final manuscript.

\section{Author details}

${ }^{1}$ General Microbiology, Department of Biosciences, University of Helsinki, P.O.Box 56, FI-00014 University of Helsinki, Helsinki, Finland. ${ }^{2}$ Present Address: Thermo Fisher Scientific, Ratastie 2, 01620 Vantaa, Finland. ${ }^{3}$ Present Address: Orion Diagnostica, Koivu-Mankkaan tie 6, 02200 Espoo, Finland. ${ }^{4}$ Present Address: Pharmacology, Faculty of Medicine, University of Helsinki, P.O.Box 63, $\mathrm{Fl}-00014$ University of Helsinki, Helsinki, Finland.

\section{Acknowledgements}

Sandra Heinzelmann, Jukka-Pekka Palomäki, Laura Huuskonen and Anna Jalava are acknowledged for skilled technical assistance. 


\section{Competing interests}

The authors declare that they have no competing interests.

\section{Availability of data and materials}

The datasets supporting the conclusions of this article are included within the article and its additional files.

\section{Funding}

The work in BW-W laboratory was supported by University of Helsinki as well as the SalWe Research Program for Personalized Diagnostics and Care (Tekes-the Finnish Funding Agency for Technology and Innovation Grant 3986/31/2013).

Received: 27 April 2016 Accepted: 28 July 2016

Published online: 04 August 2016

\section{References}

1. Plow EF, Miles LA. Plasminogen receptors in the mediation of pericellular proteolysis. Cell Differ Dev. 1990;32(3):293-8.

2. Rijken DC, Lijnen HR. New insights into the molecular mechanisms of the fibrinolytic system. J Thromb Haemost. 2009;7(1):4-13.

3. Vassalli JD, Sappino AP, Belin D. The plasminogen activator/plasmin system. J Clin Invest. 1991;88(4):1067-72.

4. Ponting CP, Marshall JM, Cederholm-Williams SA. Plasminogen: a structural review. Blood Coagul Fibrinolysis. 1992;3(5):605-14.

5. Myöhänen $\mathrm{H}$, Vaheri $\mathrm{A}$. Regulation and interactions in the activation of cell-associated plasminogen. Cell Mol Life Sci. 2004;61(22):2840-58.

6. Danø K, Andreasen PA, Grøndahl-Hansen J, Kristensen P, Nielsen LS, Skriver L. Plasminogen activators, tissue degradation, and cancer. Adv Cancer Res. 1985;44:139-266.

7. Bokarewa Ml, Jin T, Tarkowski A. Staphylococcus aureus: staphylokinase. Int J Biochem Cell Biol. 2006;38(4):504-9.

8. Bergmann S, Hammerschmidt S. Fibrinolysis and host response in bacterial infections. Thromb Haemost. 2007;98(3):512-20.

9. Caulfield AJ, Lathem WW. Substrates of the plasminogen activator protease of Yersinia pestis. Adv Exp Med Biol. 2012;954:253-60.

10. Bhattacharya S, Ploplis VA, Castellino FJ. Bacterial plasminogen receptors utilize host plasminogen system for effective invasion and dissemination. J Biomed Biotechnol. 2012;2012:482096.

11. Lähteenmäki K, Edelman S, Korhonen TK. Bacterial metastasis: the host plasminogen system in bacterial invasion. Trends Microbiol. 2005; 13(2):79-85.

12. Hurmalainen V, Edelman S, Antikainen J, Baumann M, Lähteenmäki K, Korhonen TK. Extracellular proteins of Lactobacillus crispatus enhance activation of human plasminogen. Microbiology. 2007;153(Pt 4):1112-22.

13. Antikainen J, Kuparinen V, Lähteenmäki K, Korhonen TK. Enolases from Gram-positive bacterial pathogens and commensal lactobacilli share functional similarity in virulence-associated traits. FEMS Immunol Med Microbiol. 2007:51(3):526-34.

14. Haiko J, Suomalainen M, Ojala T, Lähteenmäki K, Korhonen TK. Invited review: breaking barriers-attack on innate immune defences by omptin surface proteases of enterobacterial pathogens. Innate Immun. 2009:15(2):67-80.

15. McClintock DK, Bell PH. The mechanism of activation of human plasminogen by streptokinase. Biochem Biophys Res Commun. 1971;43(3):694-702.

16. Winram SB, Lottenberg R. The plasmin-binding protein PIr of group A streptococci is identified as glyceraldehyde-3-phosphate dehydrogenase. Microbiology. 1996;142((Pt 8)):2311-20.

17. Pancholi $V$, Fischetti VA. Alpha-enolase, a novel strong plasmin(ogen) binding protein on the surface of pathogenic streptococci. J Biol Chem. 1998:273(23):14503-15

18. van Belkum A, Melles DC, Nouwen J, van Leeuwen WB, van Wamel W, Vos MC, Wertheim HF, Verbrugh HA. Co-evolutionary aspects of human colonisation and infection by Staphylococcus aureus. Infect Genet Evol. 2009;9(1):32-47.

19. Weidenmaier C, Kokai-Kun JF, Kulauzovic E, Kohler T, Thumm G, Stoll H, Götz F, Peschel A. Differential roles of sortase-anchored surface proteins and wall teichoic acid in Staphylococcus aureus nasal colonization. Int J Med Microbiol. 2008;298(5-6):505-13.

20. Jenkins A, Diep BA, Mai TT, Vo NH, Warrener P, Suzich J, Stover CK, Sellman BR. Differential expression and roles of Staphylococcus aureus virulence determinants during colonization and disease. MBio. 2015;6(1):e02272-14

21. Kuusela P, Saksela O. Binding and activation of plasminogen at the surface of Staphylococcus aureus. Increase in affinity after conversion to the Lys form of the ligand. Eur J Biochem. 1990;193(3):759-65.

22. Mölkänen T, Tyynelä J, Helin J, Kalkkinen N, Kuusela P. Enhanced activation of bound plasminogen on Staphylococcus aureus by staphylokinase. FEBS Lett. 2002;517(1-3):72-8.

23. Kylväjä R, Kankainen M, Holm L, Westerlund-Wikström B. Adhesive polypeptides of Staphylococcus aureus identified using a novel secretion library technique in Escherichia coli. BMC Microbiol. 2011;11:117.

24. Majander K, Anton L, Antikainen J, Lång H, Brummer M, Korhonen TK, Westerlund-Wikström B. Extracellular secretion of polypeptides using a modified Escherichia coli flagellar secretion apparatus. Nat Biotechnol. 2005;23(4):475-81.

25. Edelman S, Westerlund-Wikström B, Leskelä S, Kettunen H, Rautonen $\mathrm{N}$, Apajalahti J, Korhonen TK. In vitro adhesion specificity of indigenous Lactobacilli within the avian intestinal tract. Appl Environ Microbiol. 2002;68(10):5155-9.

26. Daniel A, Singh A, Crowther LJ, Fernandes PJ, Schreiber W, Donnenberg MS. Interaction and localization studies of enteropathogenic Escherichia coli type IV bundle-forming pilus outer membrane components. Microbiology. 2006;152(8):2405-20.

27. Lehti TA, Bauchart P, Kukkonen M, Dobrindt U, Korhonen TK, WesterlundWikström B. Phylogenetic group-associated differences in regulation of the common colonization factor Mat fimbria in Escherichia coli. Mol Microbiol. 2013;87(6):1200-22.

28. Goffin C, Ghuysen JM. Multimodular penicillin-binding proteins: an enigmatic family of orthologs and paralogs. Microbiol Mol Biol Rev. 1998;62(4):1079-93.

29. Yoshida H, Kawai F, Obayashi E, Akashi S, Roper DI, Tame JR, Park SY. Crystal structures of penicillin-binding protein 3 (PBP3) from methicillinresistant Staphylococcus aureus in the apo and cefotaxime-bound forms. J Mol Biol. 2012:423(3):351-64

30. Kukkonen M, Saarela S, Lähteenmäki K, Hynönen U, Westerlund-Wikström $\mathrm{B}$, Rhen $\mathrm{M}$, Korhonen TK. Identification of two laminin-binding fimbriae, the type 1 fimbria of Salmonella enterica Serovar Typhimurium and the $\mathrm{G}$ fimbria of Escherichia coli, as plasminogen receptors. Infect Immun. 1998;66(10):4965-70

31. Moser TL, Enghild JJ, Pizzo SV, Stack MS. The extracellular matrix proteins laminin and fibronectin contain binding domains for human plasminogen and tissue plasminogen activator. J Biol Chem. 1993;268(25):18917-23.

32. Koch TK, Reuter M, Barthel D, Böhm S, van den Elsen J, Kraiczy P, Zipfel PF, Skerka C. Staphylococcus aureus proteins Sbi and Efb recruit human plasmin to degrade complement C3 and C3b. PLoS ONE. 2012;7(10):e47638.

33. Christner RB, Boyle MD. Role of staphylokinase in the acquisition of plasmin(ogen)-dependent enzymatic activity by staphylococci. J Infect Dis. 1996;173(1):104-12.

34. Zapun A, Vernet T, Pinho MG. The different shapes of cocci. FEMS Microbiol Rev. 2008:32(2):345-60.

35. Sauvage E, Kerff F, Terrak M, Ayala JA, Charlier P. The penicillin-binding proteins: structure and role in peptidoglycan biosynthesis. FEMS Microbiol Rev. 2008;32(2):234-58.

36. Yocum RR, Waxman DJ, Rasmussen JR, Strominger JL. Mechanism of penicillin action: penicillin and substrate bind covalently to the same active site serine in two bacterial D-alanine carboxypeptidases. Proc Natl Acad Sci USA. 1979:76(6):2730-4

37. Zapun A, Contreras-Martel C, Vernet T. Penicillin-binding proteins and beta-lactam resistance. FEMS Microbiol Rev. 2008;32(2):361-85.

38. Scheffers DJ, Pinho MG. Bacterial cell wall synthesis: new insights from localization studies. Microbiol Mol Biol Rev. 2005;69(4):585-607.

39. Wada A, Watanabe H. Penicillin-binding protein 1 of Staphylococcus aureus is essential for growth. J Bacteriol. 1998;180(10):2759-65.

40. Leski TA, Tomasz A. Role of penicillin-binding protein 2 (PBP2) in the antibiotic susceptibility and cell wall cross-linking of Staphylococcus aureus: 
evidence for the cooperative functioning of PBP2, PBP4, and PBP2A. J Bacteriol. 2005;187(5):1815-24.

41. Wyke AW, Ward JB, Hayes MV, Curtis NAC. A role in vivo for penicillin-binding protein-4 of Staphylococcus aureus. Eur J Biochem. 1981;119(2):389-93.

42. Pinho MG, de Lencastre $H$, Tomasz A. Cloning, characterization, and inactivation of the gene $\mathrm{pbpC}$, encoding penicillin-binding protein 3 of Staphylococcus aureus. J Bacteriol. 2000;182(4):1074-9.

43. Derbise A, Song YP, Parikh S, Fischetti VA, Pancholi V. Role of the C-terminal lysine residues of streptococcal surface enolase in Glu- and Lys-plasminogen-binding activities of group A streptococci. Infect Immun. 2004;72(1):94-105.

44. Wistedt AC, Ringdahl U, Müller-Esterl WSU. Identification of a plasminogen-binding motif in PAM, a bacterial surface protein. Mol Microbiol. 1995;18(3):569-78.

45. Sanderson-Smith ML, Dowton M, Ranson M, Walker MJ. The plasminogen-binding group A streptococcal M protein-related protein Prp binds plasminogen via arginine and histidine residues. J Bacteriol. 2007;189(4):1435-40.

46. Schenone MM, Warder SE, Martin JA, Prorok M, Castellino FJ. An internal histidine residue from the bacterial surface protein, PAM, mediates its binding to the kringle-2 domain of human plasminogen. J Pept Res. 2000;56(6):438-45.

47. Griffin JD, Ellman L. Epsilon-aminocaproic acid (EACA). Semin Thromb Hemost. 1978;5(1):27-40.

48. Silva MMCG, Thelwell C, Williams SC, Longstaff C. Regulation of fibrinolysis by $\mathrm{C}$-terminal lysines operates through plasminogen and plasmin but not tissue-type plasminogen activator. J Thromb Haemost. 2012;10(11):2354-60.

49. Bergmann S, Wild D, Diekmann O, Frank R, Bracht D, Chhatwal GS, Hammerschmidt $\mathrm{S}$. Identification of a novel plasmin(ogen)-binding motif in surface displayed a-enolase of Streptococcus pneumoniae. Mol Microbiol. 2003:49(2):411-23.

50. Mattler LE, Bang NU. Serine protease specificity for peptide chromogenic substrates. Thromb Haemost. 1977:38(4):776-92.

51. Muthukrishnan G, Quinn GA, Lamers RP, Diaz C, Cole AL, Chen S, Cole AM. Exoproteome of Staphylococcus aureus reveals putative determinants of nasal carriage. J Proteome Res. 2011;10(4):2064-78.
52. Monteiro R, Hébraud M, Chafsey I, Chambon C, Viala D, Torres C, Poeta P, Igrejas G. Surfaceome and exoproteome of a clinical sequence type 398 methicillin resistant Staphylococcus aureus strain. Biochem Biophy Rep. 2015:3:7-13.

53. Gurung M, Moon DC, Choi CW, Lee JH, Bae YC, Kim J, Lee YC, Seol SY, Cho DT, Kim SI, Lee JC. Staphylococcus aureus produces membrane-derived vesicles that induce host cell death. PLoS ONE. 2011;6(11):e27958.

54. Papasergi S, Galbo R, Lanza-Cariccio V, Domina M, Signorino G, Biondo C, Pernice I, Poyart C, Trieu-Cuot P, Teti G, Beninati C. Analysis of the Streptococcus agalactiae exoproteome. J Proteomics. 2013;89:154-64.

55. Hensbergen PJ, Klychnikov Ol, Bakker D, van Winden VJC, Ras N, Kemp AC, Cordfunke RA, Dragan I, Deelder A, Kuijper EJ, Corver J, Drijfhout JW, van Leeuwen HC. A novel secreted metalloprotease (CD2830) from Clostridium difficile cleaves specific proline sequences in LPXTG cell surface proteins. Mol Cell Proteomics. 2014;13(5):1231-44.

56. Pacheco LG, Slade SE, Seyffert N, Santos AR, Castro TL, Silva WM, Santos AV, Santos SG, Farias LM, Carvalho MA, Pimenta AM, Meyer R, Silva A, Scrivens JH, Oliveira SC, Miyoshi A, Dowson CG, Azevedo V. A combined approach for comparative exoproteome analysis of Corynebacterium pseudotuberculosis. BMC Microbiol. 2011;11(1):12.

57. Henderson B, Martin AC. Protein moonlighting: a new factor in biology and medicine. Biochem Soc Trans. 2014;42(6):1671-8.

58. Wertheim HF, Vos MC, Ott A, van Belkum A, Voss A, Kluytmans JA, van Keulen $\mathrm{PH}$, Vandenbroucke-Grauls CM, Meester MH, Verbrugh HA. Risk and outcome of nosocomial Staphylococcus aureus bacteraemia in nasal carriers versus non-carriers. Lancet. 2004;364(9435):703-5.

59. Michiels B, Appelen L, Franck B, den Heijer CDJ, Bartholomeeusen S, Coenen S. Staphylococcus aureus, including meticillin-resistant Staphylococcus aureus, among general practitioners and their patients: a crosssectional study. PLoS ONE. 2015;10(10):e0140045.

60. Gil C, Solano C, Burgui S, Latasa C, García B, Toledo-Arana A, Lasa I, Valle J. Biofilm matrix exoproteins induce a protective immune response against Staphylococcus aureus biofilm infection. Infect Immun. 2014;82(3):1017-29.

\section{Submit your next manuscript to BioMed Central and we will help you at every step:}

- We accept pre-submission inquiries

- Our selector tool helps you to find the most relevant journal

- We provide round the clock customer support

- Convenient online submission

- Thorough peer review

- Inclusion in PubMed and all major indexing services

- Maximum visibility for your research

Submit your manuscript at www.biomedcentral.com/submit
() Biomed Central 